\title{
Neonatal treatment with naloxone increases the population of Sertoli cells and sperm production in adult rats
}

\author{
Valdemiro Amaro DA SILVA Jr. ${ }^{\text {a*}}$, Aerlem Cynara S. VIEIRA ${ }^{\mathrm{a}}$, \\ Catarina Ferreira PINTO ${ }^{\mathrm{a}}$, Tarcízio Antônio R. DE PAULA ${ }^{\mathrm{b}}$, \\ Mariza B. PALMA ${ }^{\mathrm{a}}$, Marleyne José A. A. LINS AMORIM ${ }^{\mathrm{a}}$, \\ Adelmar A. AMORIM Jrc ${ }^{c}$, Raul MANHÃES-DE-CASTRO ${ }^{c}$ \\ a Departamento de Morfologia e Fisiologia Animal, Universidade Federal Rural de Pernambuco, \\ Recife, PE, Brasil, 52171-900 \\ b Departamento de Medicina Veterinária, Universidade Federal de Viçosa, Viçosa - MG - Brasil \\ c Universidade Federal de Pernambuco, Recife, PE, Brasil, 50670-901
}

(Received 27 April 2005; accepted 20 November 2005)

\begin{abstract}
Endogenous opioid peptides play an important role in the ontogenesis of the functional and morphological parameters of the seminiferous epithelium. The aim of this study was to evaluate the effects of neonatal manipulations with naloxone, an opioid antagonist, on the population of Sertoli cells and on sperm production in adult rats. Rats were assigned to receive $8 \mu \mathrm{g}$ per gram of body weight twice a day with interval of $8 \mathrm{~h}$ of naloxone and they were compared to a control group receiving saline. Naloxone groups presented the following findings when compared to the control group: increased body weight from the 2nd to the 27th day; a smaller seminiferous epithelium height, smaller seminiferous tubule diameter, increased number of Sertoli cells and daily sperm production per testis, increased daily sperm production per gram per testis and increased total length of the seminiferous tubule of the treated groups. According to our study, the neonatal treatment with naloxone during the critical period of testis development was able to change the proliferative dynamics of Sertoli cells by an intra and/or extra testicular blockage of opioid receptors, confirming the direct relation between the number of Sertoli cells and the number of spermatozoids.
\end{abstract}

naloxone / testis development / Sertoli cells / sperm production / rats

\section{INTRODUCTION}

The ontogenesis of the germ cells is associated with development of Leydig and Sertoli cells that play a key part in the proper functioning of the reproductive system in males [1,2]. The growth of Sertoli and spermatogenic cells populations happens dur- ing different periods of testicular development, presenting a distinct timing for each cellular population, with large expansion of the Sertoli cells during the perinatal period and declining shortly after birth [3].

Endogenous opioid peptides (EOP) play an important role in intragonadal regulation of testicular function of the male rat

\footnotetext{
* Corresponding author: valdemiro.amaro@bol.com.br
} 
by acting in opiate receptors that are present in Sertoli cells and modifying the proliferative response of Sertoli cells to follicle stimulating hormone (FSH) [4-6]. For example, $\beta$-endorphins are produced in the Leydig cells and regulate the function of the Sertoli cells through paracrine inhibition in neonates and in adult rats [7-9]. Opioid receptors are also present in CNS and peripheral nervous system [10].

The Sertoli cells amount established during the prepubescent period determines the final testicular size and the daily sperm production in sexually mature animals [11]. The neonatal period is therefore of the highest importance for the development of a normal spermatogenesis in the adult and the production of normal numbers of germ cells seem to depend on the size of the population of Sertoli cells at the end of the perinatal period [3, 12]. These findings have raised the question about the late effects of endogenous opioid system (EOS) manipulation during early postnatal life.

Naloxone is an opioid antagonist often used in studies of fertility, because it modulates the release and inhibition of various hormones involved with testicular function, such as somatotropin, somatostatin and prolactin [13]. It has also been widely utilized in animal models to induce and simulate physical withdrawal behavior characteristics of opioid dependence and to interact and interfere in the EOS [14].

There is experimental evidence suggesting that the manipulation of EOS, using naloxone or naltrexone during the critical period of development of the nervous system (suckling period, during the rat-21st days,) alters parameters associated with opioid function in the adult rat $[15,16]$. In male adult rats the naltrexone metabromite, another opioid antagonist with peripheral action, blocks the inhibitory effects of stress on the testosterone plasma levels, the cytoplasmatic activity of steroidogenic enzymes and become evident the involvement of opioids and peripheral opioid receptors in modulating the testis secretion of testosterone [17].

The endogen opioid receptors play a very well defined role in the neuroendocrine system, since they regulate the activity of gonadotrophic neurons and consequently the release of FSH, luteinizing hormone, production of sexual steroids and sexual behavior [18]. The FSH is the major mitotic agent responsible for the proliferation of Sertoli cells [3, 19, 20], and the reduction of the optimal level of this hormone might influence negatively the final size of testis and the sperm production, since these variables are controlled by the Sertoli cells population during the critical period of testis development [12, 21].

Naloxone acts on the opioid receptors $\mu$, $\delta$ and $\kappa[6,22,23]$ producing an important increase in the release of gonadotrophin releasing hormone $(\mathrm{GnRH})$ in normal male and female adult rats, suggesting that the opioids might induce a tonic inhibition of the gonadotrophins.

Studies of immature Sertoli cells in rats, both in vitro and in vivo, verified that $\beta$-endorphins produced inside the testis would be a paracrine modifier of proliferative response to FSH in Sertoli cells, suggesting a possible communication between Leydig cells and Sertoli cells during the perinatal testicular development, when the size of the population of these cells is established [5, 12, 24]. According to Orth [21] and Sharpe [25], the direct interaction between Leydig cells and Sertoli cells during the perinatal development of the testis is important to define the final size of the Sertoli cells population and consequently to the sperm production in the adult period since this parameter is directly related with Sertoli cells number in rat $[25,26]$, sheep [27], stallion [28], bull [29-31], swine [11] and human [32].

The functional modulations of $\beta$-endorphin in testis are intimately related with the ontogenic differences of the action of this peptide on the central liberation of hormones that interact with the pituitary in the 
beginning of puberty and sexual maturation [33]. During the perinatal period and before the puberty this opioid peptide has a modulatory paracrin action in the proliferation of Sertoli cells and to maintain the testis integrity $[7,34,35]$. In male rats sexually mature, the $\beta$-endorphin also modulates the spermatogenic process, under the synergistic control of FSH and testosterone [34, $36,37]$

The aim of this work was to study the effects of neonatal treatment with naloxone in various morphometric parameters of testicular function, such as sperm production, espermatogenic yield and the population of Sertoli cells in adult rats. There are no recent reports about possible late effects of the EOS manipulation during neonatal period on the functional and morphometric parameters of testis. This kind of analysis might contribute to a better understanding of molecular pathways involved in male fertility.

\section{MATERIAL AND METHODS}

This project was submitted to the Animal ethical committee of the Federal Rural University of Pernambuco and the Federal University of Pernambuco.

\subsection{Animals}

Wistar Rats maintained at a room temperature of $23 \pm 1{ }^{\circ} \mathrm{C}$, on a light (8:00 a.m. to $6: 00$ p.m.)-dark (6:00 p.m. to 8:00 a.m.) cycle were used. Water and food were offered ad libtum. The animals were assigned randomly to two groups (6 pups per cage) $24 \mathrm{~h}$ after birth.

\subsection{Pharmacological manipulations and experimental design}

The treated group received $8 \mu \mathrm{g}$ of naloxone hydrochloride (Rhodia Farma LTDA) per gram of body weight (sub cutaneously) and the control group received an equivalent volume of saline $(\mathrm{NaCl} 0.9 \%)$. The injections were applied twice a day, with interval of $8 \mathrm{~h}$, from the 1 st to the 20th postnatal day (suckling period). After weaning (on the 21st day), the rats were transferred to cages where they were kept (6 per cage) until 100 th days of age. Body weights were determined during the hundred days of experimental period.

\subsection{Tissue preparation}

On the 100th day of age, fifteen minutes before the initiation of perfusion tissue fixation, the rats were injected intraperitoneally with heparin at a dose of $125 \mathrm{IU} \cdot \mathrm{kg}^{-1}$ of body weight. The anesthetized rats were infused through the aorta artery with saline solution heparinized $(\mathrm{NaCl} 0.9 \%$ / $500 \mathrm{UI} \cdot \mathrm{L}^{-1}$ ) for $5 \mathrm{~min}$. After that the rats from both groups were perfused with $4 \%$ glutaraldehyde in phosphate buffer $0.01 \mathrm{M}$ $\mathrm{pH}$ 7.4. Then the testicles were removed, weighed and the testis tissue was embedded in glycol methacrylate. Four micrometer thick sections were stained with toluidine blue and were analyzed.

\subsection{Morphometry of the testis}

The tubular diameter and the height of the seminiferous tubule epithelium were measured at $100 \times$ magnification using an ocular micrometer calibrated with a stage micrometer. Twenty tubular profiles that were round or nearly round were measured and a mean was determined for each rat. The epithelium height was obtained in the same tubules utilized to determine tubular diameter. Basic morphometric data on testis composition were obtained using point counting by systematic placement of a 441point square lattice over sectioned material at 400× magnification. About 6600 points were counted for each animal. The volume of each component of the testis was established as the product of the volume density and testis volume. The specific gravity of the testis tissue was considered to be 1.0 for subsequent morphometric calculations. In order to attain a more exact measure of testis volume, $6.5 \%$ of the testis capsules was 
subtracted from the testis weight [38]. The total length of the seminiferous tubules, expressed in meters was obtained by dividing seminiferous tubule volume by $\pi \mathrm{R}^{2}$.

\subsection{Cell counts and cell numbers}

Round spermatic nuclei were counted in ten round seminiferous tubule cross-section stage VII of the cycle. These counts were corrected for section thickness and nucleus size according to Abercrombie [39], modified by Amann [40]. Because correcting nuclei that present irregular shapes is not possible with the formula mentioned earlier, Sertoli cell populations were determined from the corrected counts of Sertoli cell nucleoli per cross section of the seminiferous tubule and the total length of seminiferous tubules according to Abercrombie [39] and França [41]. The ratio of round spermatids to Sertoli cells was obtained (Sertoli cell index) from these corrected counts. The daily sperm production per testis and per gram of testis was obtained according to Rocha et al. [42] as follows:

DSP $=$ Total number of Sertoli cells per testis $\times$ the ratio of round spermatids to Sertoli cells at stage VII $\times$ stage VII relative frequency (\%) / stage VII duration (days),

Ratio of round spermatids to Sertoli cells $=$ Sertoli cell index [2],

Relative frequency of stage VII $(\%)=18.1$ [43],

Stage VII duration (days) $=2.43$ [43] .

\subsection{Statistical analysis}

The biometric and histometric data were expressed as the mean \pm standard deviation. The Tukey test was performed between groups. The significance level adopted in the statistical tests was $P<0.05$.

\section{RESULTS}

The weight of the animals of the naloxone group was significantly higher on the 3rd, 5th, 6th, 8th, 10th, 14th, 20th and
Table I. Body weight of birth to hundredth day post-natal of Wistar rat control and those treated with $8 \mu \mathrm{g}$ of naloxone hydrochloride/g/BW of birth to twentieth day post-natal.

\begin{tabular}{|c|c|c|}
\hline & \multicolumn{2}{|c|}{ Experimental groups } \\
\hline Days & $\begin{array}{l}\text { Control } \\
(n=6)\end{array}$ & $\begin{array}{c}\text { Naloxone }\left(8 \mu \mathrm{g} \cdot \mathrm{g}^{-1}\right) \\
(n=6)\end{array}$ \\
\hline 1 & $6.1 \pm 0.6$ & $6.3 \pm 0.6$ \\
\hline 2 & $6.6 \pm 0.4$ & $7.2 \pm 0.7$ \\
\hline 3 & $8.0 \pm 0.7$ & $8.9 \pm 0.7^{*}$ \\
\hline 4 & $9.2 \pm 0.9$ & $10.3 \pm 1.3$ \\
\hline 5 & $10.6 \pm 1.0$ & $12.4 \pm 0.7^{*}$ \\
\hline 6 & $12.1 \pm 0.8$ & $13.4 \pm 1.1^{*}$ \\
\hline 7 & $13.8 \pm 1.0$ & $15.6 \pm 1.7$ \\
\hline 8 & $15.3 \pm 0.6$ & $17.6 \pm 1.1^{*}$ \\
\hline 9 & $17.0 \pm 0.9$ & $17.8 \pm 1.3$ \\
\hline 10 & $19.1 \pm 1.1$ & $20.9 \pm 1.3^{*}$ \\
\hline 11 & $20.6 \pm 1.0$ & $21.9 \pm 1.3$ \\
\hline 12 & $22.1 \pm 1.4$ & $23.7 \pm 1.3$ \\
\hline 13 & $24.2 \pm 1.4$ & $25.3 \pm 1.9$ \\
\hline 14 & $25.4 \pm 0.9$ & $25.3 \pm 0.8^{*}$ \\
\hline 15 & $28.4 \pm 1.5$ & $28.2 \pm 1.5$ \\
\hline 16 & $29.5 \pm 1.7$ & $31.0 \pm 0.9$ \\
\hline 17 & $30.4 \pm 1.1$ & $31.6 \pm 1.0$ \\
\hline 18 & $32.0 \pm 1.3$ & $33.7 \pm 1.5$ \\
\hline 19 & $34.0 \pm 1.0$ & $35.4 \pm 1.3$ \\
\hline 20 & $35.9 \pm 1.9$ & $39.4 \pm 2.9^{*}$ \\
\hline 27 & $53.3 \pm 3.3$ & $60.3 \pm 5.1^{*}$ \\
\hline 34 & $107.5 \pm 4.3$ & $107.3 \pm 7.6$ \\
\hline 41 & $156.7 \pm 7.6$ & $153.8 \pm 12.4$ \\
\hline 48 & $212.5 \pm 5.2$ & $210.0 \pm 10.0$ \\
\hline 55 & $249.4 \pm 6.5$ & $240.2 \pm 19.2$ \\
\hline 62 & $253.3 \pm 9.5$ & $249.6 \pm 16.4$ \\
\hline 69 & $261.0 \pm 8.6$ & $267.6 \pm 20.3$ \\
\hline 76 & $287.0 \pm 21.9$ & $281.5 \pm 30.7$ \\
\hline 83 & $255.5 \pm 30.2$ & $265.4 \pm 19.3$ \\
\hline 90 & $309.8 \pm 22.1$ & $315.9 \pm 25.5$ \\
\hline 100 & $311.3 \pm 30.0$ & $324.3 \pm 26.0$ \\
\hline
\end{tabular}

Values are the mean $\pm \mathrm{SD}$; six animals per group. * Statistically significant $(P<0.05)$.

27th day when compared with the control group (Tab. I). Each point represents mean and standard deviation bars. Daily comparisons were done using the Tukey test. 

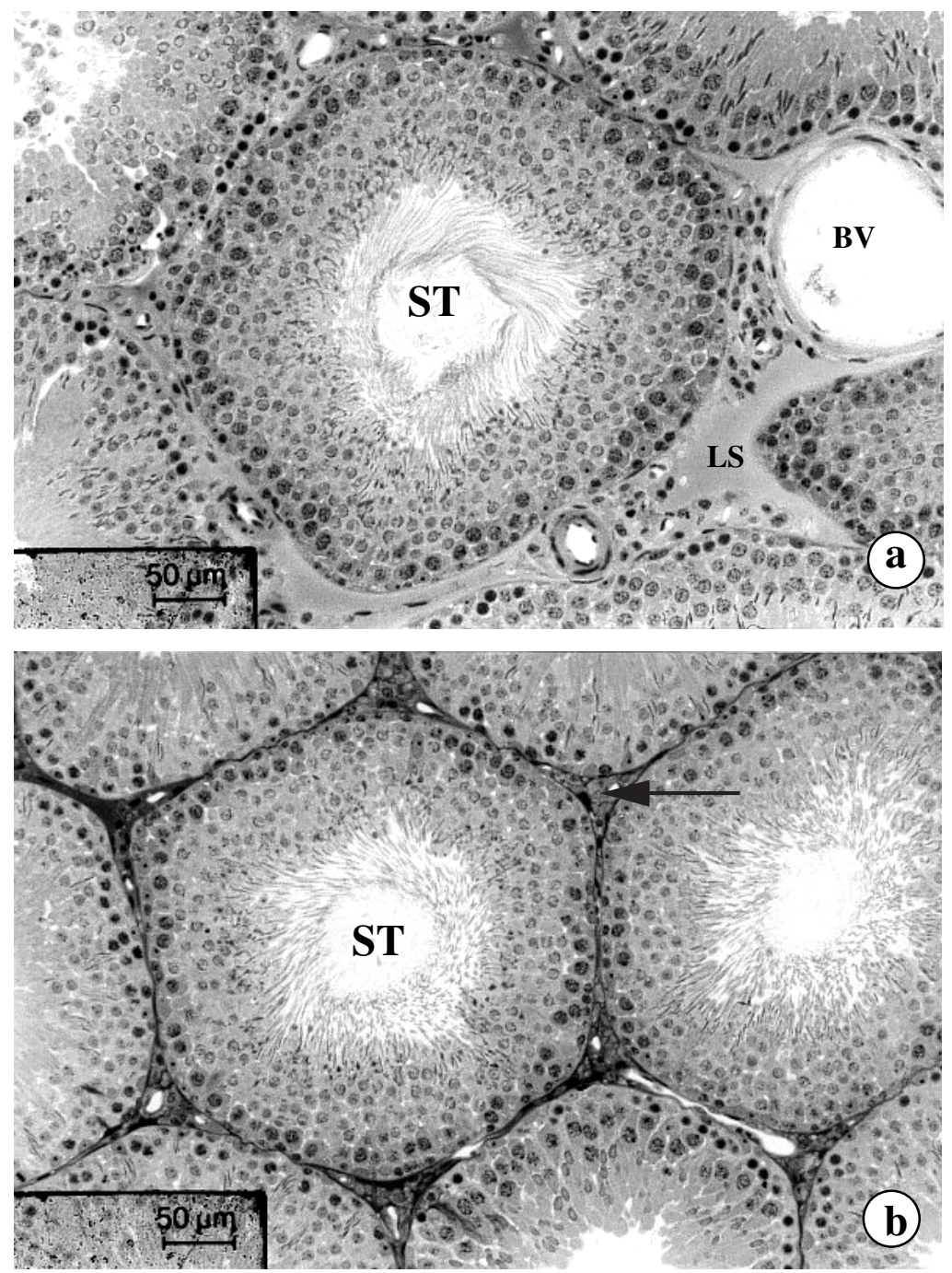

Figure 1. Cross section of the seminiferous tubule in stage VII of the epithelium seminiferous cycle (ESC) of rats at 90 days. Control group (a) to observe seminiferous tubule (ST), blood vessel (BV) and lymphatic space (LS). Barr $50 \mu \mathrm{m}$. Treated group (b) to observe seminiferous tubule (ST) and intertubular space (arrow). Barr $50 \mu \mathrm{m}$.

The body weight, testicular weight, gonadosomatic index (\%), liquid weight of the testicle, epididymal weight and seminal vesicle of the naloxone group were similar when compared with the control group. However, the epithelium height of the naloxone group was smaller than the con- trol group. As with the epithelium height, the seminiferous tubule diameter was lower for the naloxone group when compared with the control group (Fig. 1 and Tab. II).

Table III shows the data on the testis volume, seminiferous tubule volume, seminiferous epithelium, lumen, tunica propria, 
Table II. Biometric and morphometric parameters at 100th day of age of Wistar rat control and treated with $8 \mu \mathrm{g}$ of naloxone hydrochloride/g/BW from birth to the twentieth day post-natal.

\begin{tabular}{lcc}
\hline & \multicolumn{2}{c}{ Experimental groups } \\
\hline Parameters & $\begin{array}{c}\text { Control } \\
(n=6)\end{array}$ & $\begin{array}{c}\text { Naloxone }\left(8 \mu \mathrm{g} \cdot \mathrm{g}^{-1}\right) \\
(n=6)\end{array}$ \\
\hline Body weight $(\mathrm{g})$ & $311.3 \pm 30$ & $324.3 \pm 26$ \\
Testicular weight $(\mathrm{g})$ & $1.50 \pm 0.09$ & $1.56 \pm 0.07$ \\
Gonadosomatic index $(\%)$ & $0.49 \pm 0.04$ & $0.48 \pm 0.05$ \\
Liquid weight of testicle $(\mathrm{g})$ & $1.41 \pm 0.09$ & $1.46 \pm 0.06$ \\
Epididymal weight $(\mathrm{g})$ & $0.55 \pm 0.05$ & $0.54 \pm 0.04$ \\
Seminal vesicle $(\mathrm{g})$ & $1.28 \pm 0.21$ & $1.25 \pm 0.14$ \\
Seminiferous Tubule diameter $(\mu \mathrm{m})$ & $328.6 \pm 9.5$ & $309 \pm 11.8^{*}$ \\
Epithelium height $(\mu \mathrm{m})$ & $118.0 \pm 3.1$ & $110.4 \pm 5.3^{*}$ \\
\hline
\end{tabular}

Values are the mean $\pm \mathrm{SD}$; six animals per group. * Statistically significant difference $(P<0.05)$.

Table III. Volume of the testis compartments $(\mathrm{mL})$ at 100th day of age of Wistar rat control and those treated with $8 \mu \mathrm{g}$ of naloxone hydrochloride/g/BW from birth to the twentieth day post-natal.

\begin{tabular}{lcc}
\hline & \multicolumn{2}{c}{ Experimental groups } \\
\hline Parameters & $\begin{array}{c}\text { Control } \\
(n=6)\end{array}$ & $\begin{array}{c}\text { Naloxone }\left(8 \mu \mathrm{g} \cdot \mathrm{g}^{-1}\right) \\
(n=6)\end{array}$ \\
\hline Testis volume $^{1}$ & $1.41 \pm 0.09$ & $1.46 \pm 0.06$ \\
Seminiferous tubule volume $^{-1.25 \pm 0.06}$ & $1.32 \pm 0.06$ \\
Seminiferous epithelium & $1.08 \pm 0.05$ & $1.14 \pm 0.06$ \\
Lume & $0.135 \pm 0.03$ & $0.154 \pm 0.02$ \\
Tunica propria & $0.031 \pm 0.01$ & $0.032 \pm 0.01$ \\
Lymphatic space & $0.097 \pm 0.02$ & $0.077 \pm 0.02$ \\
Leydig cell & $0.026 \pm 0.005$ & $0.028 \pm 0.005$ \\
Blood vessel & $0.021 \pm 0.006$ & $0.020 \pm 0.005$ \\
\hline
\end{tabular}

Values are the mean $\pm \mathrm{SD}$; six animals per group. Statistically significant difference $(P<0.05)$. ${ }^{1}$ Exclude $6.5 \%$ of the testis capsule.

lymphatic space, Leydig cell and blood vessel of the treated group with naloxone and the control group. The volumes of the testis compartments of Wistar rat controls treated with different doses of naloxone were similar.

Table IV shows the data on the population of Sertoli cells and sperm production at the 100th day of age in the experimental groups. The numbers of round spermatids per cross section of the seminiferous tubule, Sertoli cells per cross section of the seminiferous tubule and Sertoli cell index were equal between the control and treated groups. On the contrary, Sertoli cells per testicle, total length of the seminiferous tubule, daily sperm production per testicle and per gram/testicle were significantly higher in the treated group. 
Table IV. Population of Sertoli cells and sperm production at 100th day of age of Wistar rat control and those treated with $8 \mu \mathrm{g}$ of naloxone hydrochloride/g/BW from birth to the twentieth day postnatal.

\begin{tabular}{lcc}
\hline & \multicolumn{2}{c}{ Experimental groups } \\
\cline { 2 - 3 } Parameters & $\begin{array}{c}\text { Control } \\
(n=6)\end{array}$ & $\begin{array}{c}\text { Naloxone }\left(8 \mu \mathrm{g} \cdot \mathrm{g}^{-1}\right) \\
(n=6)\end{array}$ \\
\hline Sertoli cells/cross section of seminiferous tubule & $9.1 \pm 1.6$ & $10.5 \pm 1.8$ \\
Round spermatids/cross section of seminiferous tubule & $83.1 \pm 4.2$ & $82.8 \pm 6.6$ \\
Index of Sertoli cells & $9.3 \pm 1.3$ & $8.0 \pm 1.0$ \\
Sertoli cells/testicle $\left(\times 10^{7}\right)$ & $3.4 \pm 0.6$ & $4.6 \pm 0.5^{*}$ \\
Total length of seminiferous tubule $(\mathrm{m})$ & $14.7 \pm 1.0$ & $17.6 \pm 1.3^{*}$ \\
Daily sperm production / testicle $\left(\times 10^{6}\right)$ & $23.0 \pm 2.3$ & $27.2 \pm 1.4^{*}$ \\
Daily sperm production /g / testicle $\left(\times 10^{6}\right)$ & $16.4 \pm 1.6$ & $19.0 \pm 1.0^{*}$ \\
\hline
\end{tabular}

Values are the mean $\pm \mathrm{SD}$; six animals per group. ${ }^{*}$ Statistically significant difference $(P<0.05)$.

\section{DISCUSSION}

According to the literature, this is the first morphometric analysis of Sertoli cells, daily sperm production and intrinsic yield of spermatogenesis in adult Wistar rats treated with naloxone during the period of neonatal development.

We observed that the animals treated with $8 \mu \mathrm{g}$ of naloxone per gram of body weight presented: (1) an increase of body mass from the 2 nd to the 27 th day; (2) $15 \%$ more spermatozoids and $26 \%$ more Sertoli cells when compared with the control group; (3) 14\% more intrinsic yield of spermatogenesis; (4) $16 \%$ increase in tubular length.

The tubular diameter and the epithelium height were indicative references of spermatogenesis activity in experimental and toxicological analysis [26, 43]. The seminiferous tubule diameter $(\mu \mathrm{m})$ and epithelium height $(\mu \mathrm{m})$ were reduced in treated groups. The total length of the seminiferous tubules present a direct relation with structural parameters such as testis weight, total population of Sertoli cells and daily sperm production $[2,11]$. In our analysis we see that testis and volume density (mL) did not influence the total length of the seminifer- ous tubules. However, the reduction of the tubular diameter caused the reduction of the tubular area $\left(\mu \mathrm{m}^{2}\right)$, justifying the increase of total length of seminiferous tubule and the daily sperm production of the treated animals.

We noticed a volumetric pattern of reduction of the lymphatic space and the increase of volume density of the tubular space that might also cause the increase of the total length of the seminiferous tubules. In the current experiment, the smaller tubular diameter of the treated animals did not influence the number of cells per tubular cross section or the supporting performance of the Sertoli cell (Sertoli cell index).

The present study found that body weight was positively influenced by the block of opioid receptors during post-natal treatment, confirming the findings of McLaughlin et al. [44]. According to these authors the daily dose of naltrexone would interfere with the delicate balance of the Opioid Growth Factors and the $\zeta$ (zeta) receptor, both probably related to cell proliferation and consequently to body and organ development.

Gerendai et al. [45] observed a local effect of naloxone when injected in testis of neonatal rats, through the increase of testis 
weight due to an increase in the number of sexual cords. According to Laxmi and Vijayan [46], the chronic systemic administration of m-encephalin and $\beta$-endorphin reduces plasma levels of gonadotrophins, inhibiting the incorporation of timidine ${ }^{3}[\mathrm{H}]$ into the testis tissue. They found an opposite effect in animals treated with naloxone or antiserum for $\mathrm{N}$-acetyl $\beta$-endorphin, characterizing a direct effect of opioids peptides/antagonist on gonads and the central nervous system, giving support to our results.

The testicular morphometry analysis allowed us to determine that the utilization of naloxone during the period of neonatal development of the testis was able to increase the number of Sertoli cells per testicle, the total length of the seminiferous tubule, daily sperm production per testis and daily sperm production per gram per testis.

According to our study, the neonatal treatment with naloxone during the critical period of testis development was able to change the proliferative dynamics of Sertoli cells by an intra and/or extra testicular blockage of opioid receptors, confirming the direct relation between the number of Sertoli cell and the number of spermatozoids.

\section{ACKNOWLEDGEMENTS}

We would like to thank the program of scientific initiation for undergraduates sponsor by PIBIC, UFRPE and CNPq. We are also thankful to the support of the dean of the graduate and research section of the Universidade Federal Rural de Pernambuco and to Dr João Oliveira (www.ultramarinebr.net) for his assistance during the writing of this manuscript.

\section{REFERENCES}

[1] Dadoune JP, Demoulin A. Structure and functions of the testis. In: Thibault $\mathrm{C}$, Levasseur M, Hunter RHF (Eds), Reproduction in mammals and man, Paris, Ellipses, 1993, p. 227250.

[2] França LR, Russel LD. The testis of domestic mammals. In: Male reproduction; a multidis- ciplinary overview, Madrid, Churchill Communications Europe España, 1998, p 198219.

[3] Orth JM. Proliferation of Sertoli cells in fetal and postnatal rats: a quantitative autoradiographic study. Anat Rec 1982, 203: 485-492.

[4] Fabbri A, Tsai-Morris CH, Luna S, Fraioli F, Dufau ML. Opiate receptors are present in the rat testis. Identification and localization in Sertoli cells. Endocrinology 1985, 117: 25442546 .

[5] Orth JM. FSH-induced Sertoli cell proliferation in the developing rat is modified by betaendorphin produced in the testis. Endocrinology 1986, 119:1876-1878.

[6] Zhou ZF, Xiao BL, Zhang GY, Zhuang LZ. A study of the effect of B-EP and Naloxone on the function of the hypothalamo-pituitary-testicular axis of the rat. J Androl 1990, 11:233239.

[7] Gerendai I, Shara C, Gunsalus GL, Bardin CW. The effects of opioid receptor antagonists suggest that testicular opiates regulate Sertoli and Leydig cell function in the neonatal rat. Endocrinology 1986, 118: 2039-2044.

[8] Bardin CW, Chen CC, Morris PL, Gerendai I, Boitani C, Liotta AS, Margoris A, Krieger DT. Proopiomelanocortin-derived peptides in testis, ovary, and tissues of reproduction. Recent Prog Horm Res 1987, 43: 1-28.

[9] Fabbri A. The role and regulation of testicular opioids. Trends Endocrinol Metab 1990, 1: 117-120.

[10] Gnessi L, Fabbri A, Spera G. Gonadal peptides as mediator of developmental and functional control of the testis: an integrated system with hormones and local environment. Endocr Rev 1997, 18: 541-609.

[11] França RL, Silva Jr VA, Chiarini-Garcia H, Garcia SK, Debeljuk L. Cell proliferation and hormonal changes during postnatal development of the testis in the pig. Biol Reprod 2000, 63: $1629-1636$.

[12] Orth JM. Gunsalus GL, Lamperti AA. Evidence from Sertoli-cell depleted rats indicates that spermatid number in adults depends on numbers of Sertoli cells produced during perinatal development. Endocrinology 1988, 122: 787-794.

[13] Aurich, JE, Kranski S, Parvizi N, Aurich C. Somatostatin treatment affects testicular function in stallions. Theriogenology 2003, 60: 163-174. 
[14] Laorden ML, Fuertes G, González-Cuello A, Milanés MV. Changes in catecholaminergic pathways innervating paraventricular nucleus and pituitary-adrenal axis response during morphine dependence: implication of $\alpha_{1}$ and $\alpha_{2}$ adrenoceptors. J Pharmacol Exp Ther 2000, 293: 578-293.

[15] Cabo C, Viveros MP. Effects of neonatal naltrexone on neurological and somatic development in rats of both genders. Neurotoxicol Teratol 1997, 19: 499-509.

[16] De Castro RM, Cabral-Filho JE, Costa JA, Costa FB, Gallindo MA, Hecksher CA. Neonatal treatment with Naloxone causes permanent hyperalgesia in rats. Braz J Med Biol Res 1993, 26: 747-751.

[17] Akinbami MA, Taylor MF, Collins DC, Mann DR. Effects of a peripheral and a central acting opioid antagonist on the testicular response to stress in rats. Reproductive Neuroendocrinology 1994, 59: 343-348.

[18] JA, Brown CH, Cáron RW. Endogenous opioids. In: Knobil E, Neil JD (Eds), Encyclopedia of Reproduction, San Diego, Academic Press, 1998, p 1043-1061.

[19] Almiron I, Chemes H. Spermatogenic onset. II. FSH modulates mitotic activity of germ and Sertoli cells in immature rats. Int $\mathbf{J}$ Androl 1988, 11: 235-246.

[20] Orth JM. The role of follicle-stimulating hormone in controlling Sertoli cell proliferation in testis of fetal rats. Endocrinology 1984, 115: 1248-1255.

[21] Orth JM. Cell biology of testicular development in fetus and neonate. In: Desjardins C, Ewing LL (Eds), Cell and Molecular Biology of the Testis, 1st ed, New York, Oxford University Press, 1993, p 3-42.

[22] Cícero TJ, Schmoeker PF, Meyer ER, Miller BT. Luteinizing hormone realizing mediates Naloxone's effects on serum luteinizing hormone levels in normal and morphine-sensitized male rats. Life Sci 1985, 37: 467-474.

[23] Wilkes NM, Yen SSC. Augmentation by Naloxone of efflux of LRF from superfused medial basal hypothalamus. Life Sci 1981, 28 : 2355-2359.

[24] Orth JM, Boehm R. Endorphin suppresses FSH-stimulated proliferation of isolated neonatal Sertoli cells by a pertussis toxin-sensitive mechanism. Anat Rec 1990, 226: 320327.
[25] Sharpe RM. Regulation of spermatogenesis. In: Knobil E, Neil JD (Eds) The physiology of reproduction, 2nd ed, New York, Raven Press, 1994, p 1363-1434.

[26] Berndtson WE, Thompson D.L. Changing relationships between testis size, Sertoli cell number and spermatogenesis in sprague-dawley rats. J Androl 1990, 11: 429-435.

[27] Hochereau-De Reviers MT, Monet-Kuntz C, Courot M. Spermatogenesis and Sertoli cell numbers and function in ram and bulls. $\mathrm{J}$ Reprod Fertil 1987, 34: 101-114.

[28] Johnson L, Thompson DL. Age-related and seasonal variation in the Sertoli cell population, daily sperm production and serum concentrations of follicle stimulating hormone, luteinizing hormone and testosterone in stallions. Biol Reprod 1983, 29: 777-789.

[29] Attal J Courot M. Développement testiculaire et établissement de la spermatogénèse chez le taureau. Ann Biol Anim Bioch Biophys 1963, 3: 219-241.

[30] Berndtson WE, Igboeli G, Parker WG. The numbers of Sertoli cells in mature Holstein bulls and their relationship to quantitative aspects of spermatogenesis. Biol Reprod 1987, 37: 60-67.

[31] Berndtson WE, Igboeli G, Pickett BW. Relationship of absolute number of Sertoli cells to testicular size and spermatogenesis in young beef bulls. J Anim Sci 1987, 64: 241-246.

[32] Johnson L, Zane RS, Petty CS, Neaves WB. Quantification of human Sertoli cell population: its distribution, relation to germ cell number, and age-related decline. Biol Reprod 1984, 31: 785-795.

[33] Cicero TJ, Schmoeker PF, Meyer ER, Miller BT, Bell RD, Cytron SM, Brown CC. Ontogeny of the opioid-mediated control of reproductive endocrinology in the male and female rat. J Pharmacol Exp Ther 1986, 236: 627633.

[34] Fabbri A, Dufau ML. Hormonal regulation of $\beta$-endorphin in the testis. J Steriod Biochem 1988, 30: 347-352.

[35] Morris PL, Vale WW, Bardin W. $\beta$-endorphin regulation of FSH-stimulated inhibin production is a component of a short loop system in testis. Biochem Biophys Res Commun 1987, 148: 1513-1519.

[36] Chandrasekhar V, Bartke A. The influence of $\beta$-endorphin on testicular endocrine function in adult rats. Biol Reprod 1992, 47: 1-5. 
[37] Margoris AN, Koukoulis G, Grino M, Chrousos GP. In vitro-perifused rat testes secrete $\beta$-endorphin and dynorphin: their effect on testosterone secretion. Biol Reprod 1989, 40: 776-784.

[38] Russell DL, França RL. Building a testis. Tissue Cell 1995, 27: 129-147.

[39] Abercrombie M. Estimation of nuclear populations from microtome sections. Anat Rec 1946, 94: 238-248.

[40] Amann RP. Reproductive capacity of dairy bulls. III. The effect of ejaculation frequency, unilateral vasectomy and age on spermatogenesis. Am J Anat 1962, 110(1): 49-67.

[41] França LR. Daily sperm production in Piau boars estimated from Sertoli cell population and Sertoli cell index. In: Proceedings of the 12th International Congress on Animal Reproduction, The Hague, Netherlands 1992, p 1716-1718.

[42] Rocha DCM, Debeljuk L, França LR. Exposure to constant light during testis develop- ment increase daily sperm production in adult Wistar rats. Tissue Cell 1999, 31: 372-379.

[43] Russell DL, Ettlin RA, Sinha Hikim AP, Clegg ED. Mammalian spermatogenesis. In: Russell DL, Ettlin RA, Sinha Hikim AP, Clegg ED (Eds), Histological and histopathological evaluation of the testis, Bolesta, Cache River Press 1990, p 286.

[44] Mclaughlin PJ, Tobias SW, Lang CM, Zagon IS. Chronic exposure to the opioid antagonist naltrexone during pregnancy: maternal and offspring effects. Physiol Behav 1997, 62: 501-508.

[45] Gerendai I, Nemeskéri A, Csernus V. Naloxone has a local effect on the testis of immature rats. Andrologia 1983, 15: 398403.

[46] Laxmi NA, Vijayan E. Effects of chronic systemic administration of peptides, Naloxone and $\mathrm{N}$-acetyl $\beta$-endorphin antiserum on gonadotropins and testicular function in the rat. Indian J Exp Biol 1998, 36: 361-366. 